\title{
10
}

\section{Contesting Secularism: Religious and Secular Binary Through Memory Work}

\author{
Linda Berg, Anna Johansson, Pia Laskar, \\ Lena Martinsson, Diana Mulinari, \\ and Cathrin Wasshede
}

\subsection{Introduction}

The notion of Sweden as a secular nation-state, or rather the linkage between notions of secularism and gender equality, is strong in public discourse in Sweden. Within this frame, religion is located in a traditional past and often understood as a hindrance to liberal and modern

This chapter is the result of a truly cooperative working process: the collection of the data, the analyses and the writing has been done collectively, on equal terms.

L. Berg $(\bowtie)$

Umeå Centre for Gender Studies, Umeå University, Umeå, Sweden e-mail: linda.berg@umu.se

\section{A. Johansson}

Division of Social Work and Social Pedagogy, University West, Trollhättan, Sweden

e-mail: anna.johansson@hv.se 
values. However, a number of scholars have identified the powerful presence of specific forms of Christianity in both work and family life, a presence that is so hegemonic, natural and normal that it is seldom identified as religious (Thurfjell 2019).

Since the year 2000, when state and church were separated in Sweden, the country has been officially without a state religion. Yet, even if there is an image of a sharp separation between religion and politics, Christianity holds a prominent position in the dominant culture in Sweden. In other words: Sweden has never been secular (Sigurdson 2009). In the past few decades, the Sweden Democrats, an ethnonationalist party, has shifted the issue of religion from the margins to the centre. They have emphasised Christianity as fundamental to Swedish culture and criticised the Swedish Church for being 'soft' on Islam (Haugen 2015). Large parts of the Swedish Church have challenged these statements, for example in their solidarity with refugees and in their expansion of welfare activities in the context of serious cuts in public services (Ideström and Linde 2019). In addition, feminist postcolonial scholars suggest, a number of mainstream feminist interventions on gender and religion in the Nordic

\section{P. Laskar}

Department of Research and Collections, National Historical Museums of Sweden, Stockholm, Sweden

e-mail: Pia.Laskar@gender.su.se

\section{Martinsson}

Department of Cultural Sciences, University of Gothenburg, Gothenburg, Sweden

e-mail: Lena.martinsson@gu.se

D. Mulinari

Department of Gender Studies, University of Lund, Lund, Sweden e-mail: diana.mulinari@genus.lu.se

C. Wasshede

Department of Sociology and Work Science, University of Gothenburg, Gothenburg, Västra Götalands Län, Sweden e-mail: cathrin.wasshede@socav.gu.se 
region reinforce ideologies of secularism (Keinänen 2007; Mulinari 2013; Nyhagen and Halsaa 2016).

The problematic exclusion of the role of religion with regard to women's rights in Sweden has a long tradition. For instance, mainstream Swedish feminist historiography has excluded the second-largest organisation for women's suffrage during the first decades of the twentieth century: the temperance organisation Vita Bandet (the White Ribbon) and its foundation in Christian values. The importance of Vita Bandet's politics has been downplayed, while other contemporary feminist organising, such as Fogelstadskolan and the magazine Tidevarvet, following developmental narratives of modernity and progress (Eskilsson 1991; Bengtsson 2011), have been incorporated. It not only fits better with the narrative of social-liberal feminist Swedish modernity, but we would also argue that the incorporation is performative: it has contributed to the dominant understanding of Swedish feminism as secular. Another important exclusion is the figure and visions of the Sámi pioneer Elsa Laula Renberg (1877-1931), who identified the forms of settler colonialism at play and their effects on the lives of Sámi women. The construction of the other as embodying forms of primitive religion may also explain the exclusion of Elsa Laula Renberg from the visions of a modern, secular Swedish feminism (Hirvonen 2008).

There is also another very important reason for us to question and problematise the strong normative force of Swedish secularism, or rather to critically analyse how discourses of Swedish secularism entangle with colonial and racist agendas. At the time of writing, authoritarian and repressive frames that threaten (some) religious communities are growing fast in Sweden. In the municipality of Staffanstorp-a small city in the southern part of Sweden, the region with the highest support for the Sweden Democrats - the mainstream right-wing party (Moderaterna) voted to ban girls under the age of 13 from wearing hijab in school. While their decision breaks with Swedish school regulations, this and a number of similar proposals aim to define 'the problem' (women wearing hijab) and identify the solution (violent assimilation) (Gemzöe 2018). Events like this, and they are many, create and reinforce the boundary between secular 'Swedishness' and gender equality and its Muslim other, so present in the Swedish public and political arena today. Clearly, gender 
and sexuality play a central role in the maintenance of this boundary (Giritli Nygren et al. 2018), a boundary that, to a certain extent, is reproduced within Scandinavian Gender Studies, which continue to locate religion as a minority issue instead of problematising the hegemonic discourse on secularism. We are aware that there is currently an increase in religious fundamentalism (Yuval-Davis 2011), but so are also Eurocentric forms of secular fundamentalism (Mahmood 2012), not least in Sweden (Berg et al. 2016). With a strong secular fundamentalism combined with an ignorance of the dominance of Christian dimensions, there have been increases in incidences of both Islamophobia and anti-Semitism. A change towards assimilationist policies based on 'European/Swedish values', framed through repressive forms of Eurocentric secularism (Asad et al. 2009), makes the exploration of the frictions between the religious and the secular, as well as the roles of gender, sexuality, nation and region within these discourses, an essential feminist task (Scott 2018).

In this chapter we focus on our own situatedness as feminist researchers living in Sweden and thereby explore how, where and why ideologies of secularism entangled with notions of European values and superiority become dominant. Inspired by the feminist tradition of memory work, an aim is to explore the boundary between the secular and the religious through our own experiences and from our location in Sweden. The aim is also to search for counter-memories, both in the doing of secular (gendered) selves as well as the ongoing production of the "religious other".

The title of this chapter grasps our exploration of the why and how of the diverse forms of gendered subjectivities that emerge in and through these frictions and discursive fields of secularism and religion. It also grasps our efforts to explore the contradictory ways through which some forms of Swedish banal nationalism (Billig 1995) represent Sweden as embodying a specific form of Christianity: one in accordance with the values of liberal democracy and gender equality.

Memory work challenges the dichotomy between researcher and researched, putting the researcher's self at the core of the investigation. This is relevant in a context like ours where the connection with specific forms of Christianity is silenced and obscured; where religion and religious identity, primarily Islam, but also Roman Catholicism, Orthodox Christianity and Judaism, are often located in the exotic, problematic 
and even dangerous Other. On the other hand, memory work opens for an exploration of experiences and emotions that are often marginalised, or neglected: in this case, the ambivalent relationship between feminists, located in the supposedly secular Sweden, and religion-or rather our own religious identities.

\subsection{Memory Work: Crafting Methodologies Through Feminists' Dialogues}

Our entrance into memory work developed out of numerous discussions and readings around the secular and religious binary in the political contest of increasing forms of femo-nationalism (Farris 2017) regulated through the construction of a patriarchal religious other. The challenge was to move beyond the theoretical conceptualisations and arrive at the point where we could articulate what we began to name as 'countermemories' and thereby make room for an identification of differences and similarities, of subordination and resistance between the countermemories produced and the societal hegemonic memory. Further, we wanted to use our own memories as counter-memories in order to understand the role they play in creating belongings and disbelongings, and to explore our role in our own subordination and in the subordination of others.

Memory work as developed by German socialist feminist scholar Frigga Haug, first published in Female sexualization: A collective work of memory (1987), has inspired feminist scholarship for decades (Crawford et al. 1992; Willig 2001; Cadman et al. 2001). Haug's theoretical vantage point was connected to her conceptualisation of how individuals take part in the social construction of their identity and construct themselves into existing social relations and power relations (Haug 1987: 33). Memory work (Schratz 1996; Kaufman et al. 1995; Davies et al. 1997) takes its point of departure in the collective analysis of individual written memories on a chosen topic. It also focuses on the contradictory construction of the self and others, particularly of subordinated groups, as well as the role that subordinated groups play in their own subordination. 
This construction of the self is done in relation to hegemonic cultural norms regarding what is deemed normal, right and natural. The collective analysis of the memories helps us see both adaptations and resistance to hegemonic norms and to the location of the subject within these norms (Esseveld 1999: 109-111).

The strengths of the method are its theoretical basis and its collaborative frame. The theoretical frame allows for analysis that goes beyond the experiential, and the collaborative edge opens for naming experiences that are often silenced or difficult to articulate. The method is not selfreferential, but takes as a point of departure the analysis of collective experiences, identifying the ambivalent processes of internalisation of cultural norms and societal agendas.

While our group has been inspired by the method, we also have problematised some of the a priori assumptions regarding the conceptualisation of experience, or rather the ways that the method conceptualises experiences at the crossroads between subjectivity and memory. In line with scholars working within the field of memory (Onyx and Small 2001; Petö and Phoenix 2019), we understand memories as fractured, contradictory and often selective. Hegemonic discourses regulate not only what we can remember, but also who can remember, and whose memories will be considered 'true' or worth remembering (Scott 1992; Butler 2001). While memories are central for constructions of identity and subjectivity, unconscious processes hinder 'remembering' and shape and regulate the ways through which memories are articulated through desires and emotions outside the scope of what is to be remembered. We do not consider the process of writing and analysing memories as one in which our 'repressed voices' come to the surface. Rather, we see remembering, or memorialising, as a performative and situated act through which we create relations and identities. As formulated by Sara Ahmed (2017: 36-44), feminist work can be seen as an effort to remember things we sometimes wish would disappear, rather than things we have forgotten.

However, we have worked in line with Haug's tradition, taking as a point of departure that the memories written down are true memories, not in the sense that the memories provide evidence of past events, but in the sense that the memories are defined and selected as such and differentiated by the members of the group from a fantasy or a fiction. The work 
process did thus not move from experiences impossible to name in collective articulation, from trauma to the emancipatory experiencing of wording pain. Instead, our collective work opened up for the possibility of sharing memories that we had experienced as extremely personal and not worthy of interpretation outside individual frames. The method provided a space to reflect on how the binary opposition between secularism and religion is inscribed in the ways through which gendered subjectivity is created and reproduced in Sweden. This allowed for a productive move from the object of study of our research project on gender, religion and secularism, to what religion and secularism do to our bodies, our personal histories and collective stories, as feminist scholars living in Sweden.

Memory work also provided a space in which we could talk to each other, transcending what we experience as the traditional forms of academic collaboration (Jansson et al. 2009: 231). The method created a field of collaboration where we could see/learn/listen to each other beyond our individual academic positions. Memory work shifted the language with which we spoke to each other, from an abstract, disembodied one, to one doing 'theory in the flesh' as Chicano feminist Cherrie Moraga would name it (Moraga and Anzaldúa 1983).

The methodology developed by Haug (1992) prescribed a strict protocol for how the work should be done. However, over the years the different steps and procedures have been adapted and modified (Crawford et al. 1992; Cadman et al. 2001). This methodology has also inspired our group. Even so, our work process has by and large followed the three phases recommended (Langdridge et al. 2012): (1) production of memories (formation of a group, selection of topic/theme and writing of the memories); (2) collective analysis of the memories (sharing each other's texts, searching for similarities and differences in the individual memories and developing themes together); and (3) rewriting, integration and building of theory.

All of the group members are located within Swedish academia and have been socialised in its secular and middle-class academic culture. We also belong to the field of Gender Studies and to a number of feminist traditions. There are, however, some important differences in the group regarding class, sexuality, nationality, regionality, ethnicity, age and how we are racialised. Social scientist Niamh Stephenson (2001) suggests 
that the emphasis on the 'collective subject' of memory work risks an overemphasis on identifying commonalities between group members at the expense of exploring differences. However, the discussion of differences regarding social identities in the group opened for a number of dilemmas, taking into account the heterogeneity among us, the members of the group. We know very little of what would have happened if class background, heteronormativity or whiteness and religious background, the relevant differences among the group members, had been at the core of the analysis. We would like to argue, however, that our emphasis on similarities and commonalities functioned as a successful analytical tool in identifying a number of relevant topics that have not been explored in Scandinavian Gender scholarship.

We followed the memory work techniques in the sense that we tried to create detailed descriptions of the environment, emotions and embodied experiences, and avoided explanations, interpretations and generalisations (Willig 2001: 127-128). We also followed the techniques in the disidentification of the writer/author, for example through writing our memories in the third person (ibid.). In first-person narration things/ details are often taken for granted, left out or considered unimportant and embarrassing. We might call this choice of third-person narration historicising or distancing the narrator. We decided on the writing of two memories each. The size of the memories varied from half a page (what had been decided) to two pages (what some members provided). Another strategy through which we have tried to further develop the method is through the experience of co-writing, an experience that created dilemmas (sometimes disagreements) regarding the selection of the memories and the ways to organise them. The analysis was framed by traditional qualitative methods, mostly content analysis with a focus on topics, commonalities and differences. A narrative inspired by discursive frame interpretation would provide other readings but was outside the scope of this first explorative theoretical effort.

It is needless to say that we opened Pandora's box through this work. We were astonished by the many similarities but also by the many frictions we came across in the material. While it was seductive and easy to create a similar pattern based on a linear developmental narrative to relate memories, for example, from the little believing child to the secular adult, 
our memories pointed to an ongoing performance embodied with contradictions in a continuous becoming of a gendered secular subjectfrictions ranging from diffuse feelings of discomfort to quite violent experiences of exclusion and marginalisation. It is not the pushing away (of religion) per se that causes the friction, but the sticky, contradictory and uneven struggle and pressure between what is understood as religious and as secular (Tsing 2005: 1).

\subsection{A Room of her Own}

In the following text, from two members of the group, memories are shaped by an emotional frame regulated by place and materiality. In the memories, the girl's intimate and private bedroom becomes a sacred space, through the ritual of secretly praying to God at bedtime. In contrast to forms of institutional religion located in public religious settings, the girl's bedroom might be understood as the absolute opposite, a 'room of her own', where secrets can be kept in the practice of praying.

Every evening she secretly prays the evening prayer. She has the door closed and lies down in her bed under the blanket and she puts her hands together in prayer. Next to her lies a dog of cloth, a dog whose tail she uses when she masturbates. She whispers the prayer because it feels more real then: that God would hear the prayer better if it is also audible in the room. She is careful to give thanks for everything that has been good, all the good she has in her life-like a home, a family and such. She also tells about everything that burdens her-anxieties, feelings of being lonely and abandoned - and she asks for help. 'Please, good God, help me,' she whispers. Sometimes she cries silently and feels some comfort that God may hear her, may be there, may be helping her.

The praying, and probably the masturbation, is narrated as performed behind a closed door, even under the bedcovers, presumably without the secularised parents knowing about it. The closed door may be seen both as a symbol of the boundary between the secular and the religious $\mathrm{room} / \mathrm{space}$, and as a materiality (re)creating this very boundary. It is a 
sign of the friction between the parents' secular world and the girl's own religious world. She needs to shut the parents out to be able to pray, to be able to dwell in her own created religious space. Through the narrative, religion is created as something secret.

Both in this and in the following memory, the bed and the blanket are materialities that frame the act of praying. Hidden under the blanket, the girls can put their hands together to pray. It is dark, and the 'ordinary' social interactions that take place during daytime have come to an end. The girls are alone and free during this time of the evening - a time that in itself can be seen as a friction: between day and night, light and darkness, being awake and falling asleep, being among others and being alone.

While her mother did not see, she secretly prayed in the evening, especially those evenings when it hurt the most. No one could say anything, if there was anyone who might come to her. [...] It would not hurt to try to pray a little. As long as no one else saw. It became a secret between her and Somebody. A conversation about things that made her sad, about things she dreamed about and about the hope that everything was really much bigger.

In both memories, the girls detach and distance themselves from their families, even if the act of praying also includes the parents in a very active way through thoughts about and concern for them. Another intense relation takes place instead: the one between the girl and God/ Somebody. She talks to God/Somebody. The ritual of praying creates and establishes a connection with a God/Somebody who listens to sorrows and feelings of loneliness, who provides understanding, comfort, help and hope. Another belonging than that to the family is made possible. Parallel to these comforting feelings, the girls experience feelings of shame when praying:

She is ashamed of praying to God. Her parents think believing people are naive, childish and irresponsible. Maybe even a little bit stupid. They have said things like 'Christians do not take responsibility for themselves, but leave their responsibility to God'. They are represented as corny and a little unworldly. [...] It is a kind of forbidden area. Sometimes it happens that 
her mother or father enters her room when she lies there whispering to God. The shame is felt like a burning flame and she rips her hands apart, becomes silent and then talks to them in a cheerful voice. Her heart is beating, and she is afraid that they will understand what she is doing.

The girls have learned that religious people have the wrong ideas, that they lack a critical perspective, and that they are, in one way or another, stupid - almost as the non-modern irrational position — and that they are aloof from the world.

Her mother, father and uncle talked about how superstitious and credulous the religious people were. 'Do not act stupid,' her father said. Words that felt challenging, almost threatening, but at the same time filled with pride.

To feel a belonging to this religious detached world makes the girls feel ashamed. Thus, the modern position is created through shame of being (too) close to the other side, maybe even through feelings of fear and of doing the 'wrong' thing. Shame has been a fundamental and contested emotion in feminist theory and practice (Fischer 2018), since gendered shame is seen as reinforcing patriarchy. In our analysis, shame is linked to the desire to belong to what is defined as undesirable, outside the needs of modern citizens, a shame of desiring maybe not so much the forbidden, but what is coded as ignorant, traditional and backward.

\subsection{Communities of Belonging and Disbelonging}

Feminist sociologist Nira Yuval-Davis's (2011) study of the politics of belonging conceptualises different analytical levels which need to be explored as social locations, identifications and emotional attachments, as well as ethical and political values. In the following, memories of belonging are remembered through the role of rituals, or rather through how rituals create inclusion (for some) but may reinforce exclusion and marginalisation (for others). 
Specific spaces and times are designated for the sacred, and organised through certain activities and objects: buildings, songs, prayers, food. Confirmation (affirmation of baptism) in the state's Swedish Church, which is Lutheran, is one example of religious practices that we found in some of our memory work, a practice that could be described as a religious 'rites of passage' from childhood to adolescence. In Sweden, while ideologies of secularism are foundational to societal life, the Swedish Church is located as providing a spiritual frame that does not challenge the core of secularism. Often religious rites such as confirmation are spoken about (and understood) as Swedish 'traditions'.

In some of our memories, the Lutheran confirmation is associated with a multitude of objects, relations and places through which belonging as well as disbelonging are performed. In the following, the narrator describes the confirmation camp as a mythical place of happiness, sweetness, adventure and community:

They spoke about camps on islands outside the town, confirmation camps with names that felt mythical, far away, where there was sun, everyone was bathing, playing and eating ice cream. She remembers how they talked about it with excitement in their voices; they would be involved in things that could hardly be mentioned. They would get gifts and have parties with family and friends and also go to a camp.

Parallel to the romanticising words about the confirmation camp, the memory also ends with dismissal:

Corny with confirmation: long white dresses as some fucking Lucia procession. And taking tests about Christian things in the church. Boring.

The white dresses often worn in confirmations are here compared to 'Lucia', a Swedish tradition celebrated on 13 December, with girls and boys clad in full-length white gowns, singing for the light to return, a tradition which in the narrative is dismissed by the word fucking. Instead of feeling a painful disbelonging, the girl turns her emotions into contempt and probably also anger: 
The classmates lived with their families in terraced houses in the posh area. They did not live with their mother in a small flat in public housing. Clearly, she would not be in a bloody camp with them.

Here, the girl's struggle also involves a class dimension. The desirable girls at the confirmation camp are portrayed as middle-class people living with their nuclear family in terraced houses in the posh area, while the girl herself lives alone with her mother in a public housing estate. In an effort to handle the friction between the religious and the secular, class positioning becomes an aspect of the doing of secularism. Religion is pushed away at the same time as middle-class people are pushed away.

In another story, a religious course taking place within the setting of the Catholic Church in a Latin American country is associated with friendship, of being admired and being part of the group:

She loves going to the course. She meets girls different from her school friends, girls that think she is 'smart' [...]. She is good at this thing of telling stories. And she loves the stories. She also enjoys the gossip very much.

One aspect of gossiping with the girls is to share rumours regarding religious practices such as: 'if you take a bit of the wafer/hostia [host] instead of eating it whole, then Christ's blood will get into your body and will get you pregnant'. However, the girl has explained to the other girls that 'this cannot be the case', since her mother has provided her with books 'on human biology': 'Women and men make children'. The biology books can be understood as materialities mobilised by the girl to 'do the secular'.

Even though the girl argues against the idea of getting pregnant through Christ's blood, she still has decided to break the wafer/hostia and get Jesus' blood 'into' her, with the aim of 'being a better Christian'. Thus, the wafer/hostia is another significant artefact that is mobilised, but now in order to create the religious, pious self. It could be said that the girl handles the frictions and contradictions that arise between the religious beliefs and the scientific explanations through a reinterpretation of the story and the ritual. In this way she may still be 'smart' and provide scientific explanations from books and reject certain religious ideas, and at 
the same time be part of the group of girls and the community of the Church.

The mother appears in the story as a character who represents a secular position. While the aunt has regularly taken the girl to the church classes, the mother has not been involved. When the mother follows her for the first time it has a particular meaning to the girl:

She remembers being happy and proud. This day is the first day, of the long months of going to the preparation course, that her mother has followed her to her church class.

The reason the mother goes to the church with her is to put her on the list of those who will take communion. The girl does not remember the content of the conversation that takes place between her mother and the priest, only that the room they are in is 'cold' and all the different emotions that are evoked as she hears her mother's voice becoming louder. The girl describes herself as being 'ashamed' as well as 'angry' over her mother, who is 'destroying' what the girl has so 'patiently' created. The mother is defined as 'powerful'. The girl remembers walking back home afterwards and her mother scolding her:

'You never told me that the girls from the orphanage were going to take communion in their school uniforms, but you and all the others in fancy communion dresses. How come?' [...] She goes slowly, dragging her feet; she knows her mother hates that. 'You do it together with the girls in school uniform or you do not do it at all. Faith is not a fashion show for those with money to buy expensive dresses'.

Once again, a friction between the secular and the religious arises, and once again the mother represents a secular position introducing a class aspect. The mother expects the daughter to show solidarity with the 'girls from the orphanage' and demands from her that she too wears her school uniform. But the girl is torn:

She wanted the dress. Her aunt said she could look like an angel. She did not want to hurt anyone. Particularly not the girls from the orphanage, 
whom she liked so much and who had been so kind to her. She just wanted the dress and the party and being part of something, being as everybody else. She felt guilty of her desire. [...] 'I will not do it in the public-school uniform,' she whispered.

To wear the school uniform would mean to surrender to her mother and her attempt to force her to choose the values of equality and solidarity before the longing to belong and be 'like everybody else'. Similar in significance to the wafer/hostia and the blood of Christ, the white dress is both a symbol of a religious self, the looking and feeling like 'an angel', and a way to embody (materialise) this angel-like experience:

She never dressed in white. She never again felt like an angel.

To the mother portrayed in the narrative, the dress is seen as a class marker/division, while for the girl/daughter it is mobilised to create a gendered, religious self and become part of a group and a community.

\subsection{The Religious Maternal Body}

As we have seen, the frictions between religiosity and secularity arise, and are being played out, in specific situations and relationships. The character of the mother, as well as the grandmother, return in several memories, and repeatedly play significant parts in the work of subjectification of the girls. Their bodies, spaces or interventions work at the same time as nodes as well as frames of abjection in the different narratives, and their positions and roles, rather than being predictable, are both shifting and contradictory. Thus, there is not one single maternal body but a multitude of bodies that are mobilised to produce different kinds of selves: gendered, classed, religious, as well as secular, etc.

In the following memory a young woman receives a visit from her deeply religious mother, who recently joined a religious group that she now lives with, a group that the daughter considers 'a sect': 
One day, the mother just stands outside her front door. Dressed in a green, fluffy shirt. She smiles. Looks like usual. But the daughter knows nothing is as usual. She knows that at any moment the mum's voice can get a brassy and easy ecstatic tone. [...] At any time, the mother will begin to proclaim 'the word of God' and it will no longer be possible to connect. [...] The mother cannot talk about something else than God, God's will, God's plan, God's word.

The mother who appears in the narrative smiles and looks 'as usual', but it is an illusion, since when she preaches the word of God she is no longer possible to reason with or keep up a conversation with. The religious body in this situation and relation is positioned as irrational and unreliable:

The mother is standing outside her door. The daughter wishes that she could lean her head against the voluminous bosom that looks so soft. But it is impossible. 'I don't want to see you,' she says, with tears stuck in her throat. The mother's face falls apart. She stretches out her hand. The daughter quickly closes the front door, locks it from the inside with hands that are shaking, and rushes into the small toilet in the hallway.

In this passage, the mother's body is depicted as soft and maternal, a body to seek comfort from and fuse with. Yet, at the same time, the mother's ecstatic (religious) lack of (secular) reason embodies a threat to absorb the daughter. The daughter's emotions are contradictory.

Historically, the female body has been seen as leaking and permeable in contrast to the male body as solid with sharp boundaries (Longhurst 1995). However, in the memory the mother's body appears to be rejected not for being associated with the maternal/feminine but because of her religious pathos and hysterias/husteràs lack of logos (Hendrix 2015: 50). Religious ecstasy and a void without reason-not the mother's desired bosom-become dangerously absorptive. As a young woman, in the creating of a self in relation to the world outside of family, the daughter needs to keep a distance and protect herself. Once again, the door plays an important part as both a symbolic and a material boundary. The mother is not allowed to come into her daughter's home but needs to be 
kept outside, the door being both shut and locked. The emerging self needs to disidentify itself from a religious other.

In contrast to the memories in which the girls had to distance themselves from the maternal bodies to be able to engage in a relationship with God and practice the religious and/or be part of a community of faith, the girl in this memory is older, and she rather distances herself from her parent to 'get away' from religion, as it is being perceived as scary and dangerous.

In all the memories, the body is located and remembered through specific spaces, spaces of independence, freedom or danger, as well of safety and protection. The private, intimate bedroom appears as a significant location for the doing of religiosity. In a different memory, with a much younger girl, that takes place in relation to the grandmother as a significant other, religion is performed through objects in the room in conjunction with the embodied ritual of praying:

In the grandmother's little room everything reminds her of her faith. The heavy brass bowl with a lid containing small folded papers with Bible verses, the black Bible with its thin pages where the grandmother's curly writing appears on each side. On the walls there are several paintings of Jesus, the Son of God. [...] She and her grandmother read 'God who loves the children' together, with hands clasped, and they are very serious. The girl is a child God loves - it feels warm inside to know it. The grandmother's room is a room to feel safe in.

The grandmother also appears in another memory, in which the kitchen is described as a possible and significant place for the religious. The little girl is growing up in an environment where the religious life in the evangelical church of her grandmother and grandfather is dismissed in a covert way by her parents. It is a hidden truth, and a complex divide between the parents and grandparents that the girl is well aware about. However, sometimes this divide is bridged and some of grandma's narratives are reproduced also by the girl's mother. One example of this is a story of when the grandma, when she was young, refused to let the priest from the national church baptise her newborn child, who was going to die within a couple of hours. The little daughter had done no harm, the 
grandma explained; God will embrace her. Grandma always stressed that she had her own relationship with God, as this time when she and the girl are alone in the kitchen:

The grandma says that she speaks to God when she is in her kitchen and prepares the food. She doesn't need any priest. The granddaughter likes what she is told. She sits on a high stool painted in red and turquoise. The grandma stirs in a red plastic bowl and says that God is not so special. God is with her, has always been with her. It feels fine and cozy there in the kitchen.

Grandma is firm: no one person is better than any other. The belief, the narrative about God, becomes a general description of how to understand oneself and others. The girl can grasp it without coming into conflict with the mother.

In the space of the bedroom, as well as of the kitchen, there is a making of religious subjectivity. Yet it is not made primarily through personal experiences of God, nor through performing certain rituals or holding certain beliefs, but rather through bonds and relationships of love and need, in these cases between girls and their grandmothers. In the latter memories the closeness with the grandmother depends maybe not only on the warm and personal God image but also on a narrative about equality and strong women that the girl recognises as being told by her mother as well. The divide between the mother and grandmother is bridged for a moment. In our material, religious significant others-sometimes mothers and grandmothers (and sometimes fathers or aunts) - appear as active in the construction of the girls' subjectivities.

In the making of religious subjectivity, both divides and frictions are created and bridged. In contrast to the young woman who disidentifies with a religious other, forcefully disrupting the mother-daughter bond, the small girls are depicted as strengthening their bonds with significant others through their talk about religion, God and Jesus and even longing to become part of their grandmother's/family's religious world. In our memories, religion seems to function as a nodal or a floating signifier where childhood memories articulate feelings both of safety and belonging but also emotions of exclusion, danger and threat. 


\subsection{Nation, Eurocentric Modernity and the Secular (Gendered) Self}

A recurrent theme in our memory work is the doing of territories, regions and frontiers in the ongoing emergence of the secular self. What we see is how the religious in the memories is located in specific spaces, or the longing for these spaces, where gendered subjectivity is created through a number of frictions, as well as shame for this longing.

'Ohhhh, it is so beautiful, the Catholic Church [...] the rituals, they are so powerful. I love them.' She knows that it is wrong, but she feels a guilty pleasure that a Swedish person celebrates something that for a second in her life she can feel belongs to her. She feels guilty for this sick desire to be liked, accepted, that some part of her, or rather what the Swedish person thinks is her, is valuable to them.

In this memory we found both reiterations of colonial discourses which produce Sweden and Europe, Swedes and Europeans, as rational, modern and a bit boring, and notions of Latin America as the 'other', exotic, mythical and religious. We would like to focus on the double alienation in the memory as an ongoing struggle to become a recognised subject. The memory is about a meeting between the 'she' (the producer of the memory) and a woman, called the 'Swedish person', who expresses admiration for the 'non-Swedish' Catholic Church, which causes an amount of contradictory feelings for the 'she'/narrator. She feels desired in her identity as Catholic, but also as a 'bad', and therefore shameful, representation of the Other, the non-Swedish that does not share the 'Swedish person's delight for the Catholic Church.

While the memory of the fetishised Catholic Church in Latin America is an example of Europe and Sweden re-established as the core of modernity and rationality, the next examples show how different places in Sweden are understood as lagging behind, less modern, more religious and therefore subordinated. In the following memory, modernity and the secular discourse are connected with urbanity, while religion and death are things that belong to the countryside, far from the newly created suburbs with their brand-new houses: 
There is no heirloom in the home. No flea-market bargain, no old stuff. It is modern. The family dresses modern. The house is new; no one has lived there before. The grandparents are coming to visit. The mother hides the wine-rack in a cupboard in the kitchen. The pack of cards is also put away. It's the 1970s.

Modernity is materialised in buildings, things and clothes, and so are the disconnections, breaks and processes of otherings. It might have been difficult for the girl to understand why the wine-rack and the pack of cards were hidden. But the free-church community to which the grandparents belonged were total abstainers. For them, the use of a wine-rack in the kitchen was an act of non-believing and of not living in accordance with the religious community. The girls' parents were very well aware of this. The wine-rack was a way to disconnect. The children learnt that there was a need to hide things that the old religious people would not tolerate, such as the wine-rack and a pack of cards. While grandma and grandpa were there, the children would pretend to live another life, belonging to another community. In contrast to 'the old grandma and grandpa', the young mother becomes an expression of modernity:

The mother and her daughters leave the suburb of the big city to visit the parents of the mother, who live in a small society in L-land. The transistor radio is on the front seat. The mother listens to $\mathrm{P} 1$ [radio] while she is driving. It is sunny. Just before they arrive, she drives into a parking lot and picks out the curlers. She pulls her fingers through the locks. She is pretty and modern. It's the 1960s.

The mother's modern style, that she looks so pretty, drives the car and listens to the news on radio-all in a happiness marked with the sunny feeling-makes the young mother a representation of the future. The feeling becomes different when L-land is described:

In L-land, everyone is a believer. None of the cousin families lives in L-land; everyone has moved away from there. Believers may not be stupid, but nerdy, miserable, they are not really modern. They are wrong. The mom thinks that nature is falling down on her in L-land. She feels trapped. She is contemptuous of something and so are her daughters, perhaps the father 
too. No one knows. The atmosphere in the car is always tense when they go home.

For the little girl, the countryside far away from the home in the suburbs becomes inseparable from faith, from religion. It is a place from which people move; it has a nature that is disliked by her mother. It is a place with a lot of free churches. In L-land the mother becomes stressed. From the girl's position, people who believe are strange and corny, living far away. It is not a modern place.

In the Mission church [Mission Covenant Church of Sweden] in L-land, funeral services are being held. [...] In L-land, people die. It does not happen in the suburb outside the big city. In the area with new villas, fast-built houses, there is no church either, or free churches. Everyone is young at one and the same time.

The new suburbs, with only young people and new houses, are portrayed as the frontier of modernity and the future, a place where you do not die. In the examples of how territories are intertwined, religion is located in the Global South, and projected onto the Swedish rural spaces. These places are supposed to be in line with an imagined past, though still existing, and less developed time. Modernity is placed in the Global North, and in the cities and the new suburbs. In the suburb the secular little girl seems to be 'at home'. In the memory with the grown-up woman and the Catholic Church, 'home' is instead taken away from her. As Saba Mahmood (2012) emphasises, faith cannot be separated from subjectification, and religiosity/spirituality is nothing that can be left at home-in other spaces, other territories.

\subsection{Politics, Religion and Gender Subjectivity}

In a memory of being a teenager during the late 1980s, the tension between politics and religion, or rather how this tension is understood in terms of class belonging and political struggle, is identified. 
The girl moved from the county of Norrbotten to a city in Västerbotten, an area of middle-class people with 'suitable' Christian knowledge:

Recently moved from the northern county, called 'lappjäntan' (invective for Samí girl), she could not remember a single sentence from the Bible or calculate mathematics on time. The classmates lived with their families in terraced houses in Gustavslund.

Here, the religious others (her classmates in Gustavslund) become connected to middle-class identities from which her mother clearly distances the family, positioning the family as atheist-and as people who do not participate in confirmation camps. To feel trust in God is wrong. Instead they should identify as political and, as such, more rational. In the memory the girl remembers her mother asserting:

If we want something to change, we have to do it ourselves, organize ourselves politically, not as the 'right-wing bastards' then. Knowledge is important; hocus-pocus and paying money to the church is just stupid.

It seems that a secular position was ideologically important in the doing of a working-class subjectivity_-in contrast to the doing of middle class. The divide between religion and politics is very clear. The girl learns about religion as hocus-pocus at the same time as she learns about class politics, or rather she learns that religion is against her mother's (and her class') notion of social justice. On the other side of religion stand knowledge and collective organising; the left-wing movement is constructed as the rational one. It can be understood as a creation of a secular position in contrast to imagined religious others, but it can also be seen as a reaction against inequalities - with a verbalised act of pride against the regional differences and as a critique against privileged Christian middle class.

The division between religion and politics is reiterated in another memory of a young girl and her path to political commitment:

In the 1970s, she left the Swedish Church and sold the gold cross she had received at her confirmation. Religion was now an opium for the peopleshe participated when the Stockholm-based Socialism or Barbarism distributed flyers [saying 'religion is an opium for the people'] during a 
gathering that Children of God and other revival Christian communities had at Sergels Square in the early 1970s. She felt that they were mentally disturbed when they stood there and collectively prayed to God and spoke in tongues.

In this memory, the political practice is set up against the religious at the same city square. The notion of religious faith and practices as absurd or, as here, mentally disturbed, is a recurrent theme through all our memories. Being political (or being a feminist) seems to be equated with being secular and therefore rational in the memories.

\subsection{Concluding Reflections}

We have read the shared memories as counter-memories illuminating the infinite strategies that the members of the group develop to transcend the binary opposition between the religious and the secular in a context where secularism as an ideology is embedded in societal power relations.

Through this memory work, we have learned about the contradictions and frictions shaping feelings and emotions in the ongoing production of Swedish secularity, and how these, often silenced contradictory feelings may act upon our reproduction of problematic (and dangerous) boundaries. We have analysed how othering processes through the binary opposition between religion and secularism become a complex net, dividing individuals, families and territories. What we believe we found was the abjection of religion and the normalisation of secularism in the making of Swedish modernity.

There is a risk of infantilising these stories, not listening to the powerful forms of spirituality evolving in the search for comfort and support, a search where the self often prioritises other members of the family. There is much to learn about how children experience the boundary between the sacred and the profane, but particularly about how relatedness and connectedness towards others are explored. It's important to stress that in our data, in these memories from child-and adulthoods, the stories about interactions with religion and secularism are part of a performative language frame where (behavioural) norms are being played out through, 
among other things, the making of religion and secularism as hierarchically placed opposites.

The construction of gender-equality frames through the reinforcement of the heteronormative binary (man/woman) challenges other forms of family bonds, particularly matrilineal ones. While these gender policies have been successful in developing women's autonomy, they have also aimed to prioritise women's dependency on 'experts', and have sometimes made attachments to mothers, grandmothers and female communities coded as traditional. Maybe it can be defined as a violent effect of Swedish modernity, with its shift from matrilineal bonds to public patriarchy.

There is much to learn about how relatedness and connectedness with others are often coupled with feelings of shame, with the autonomous individual at the core of Swedish notions of gender equality and modernity. In the memories there is also a longing for other forms of existential meaning and interdependence. However, also present in the memories is how the journey towards secularism was a path towards utopian dreams, among them our encounter with feminism as a theory and as a community of belonging.

We have also learned about our own role in reproducing the subordination of the 'other', even when we ourselves at times embody this 'other'. The striving for the rationality and autonomy of the Cartesian self, mirrored in our desire to belong to communities of knowledge (at the university), is combined, however, with different forms of resistance to this very position. Although Christianity is not at all othered to the same extent as, for example, Islam in postcolonial Sweden, we can see how our processes towards performing secular subjects have also been part of a distancing primarily against generations of women carrying religious traditions as evident parts of life. Reactions against religious values, worldviews and material practices (artefacts/symbols/traditions) in many cases became reactions against women's worlds, private as well as public, and the raising of the secular flag in the disidentification from the maternal, could sometimes be seen to be just as patriarchal as the Church itself.

In a time of increasing religious fundamentalism and Eurocentric fundamentalist secularism in Europe, the counter-memories show that feminist resistance and visions of other futures may be located in the systematic transgressing and the everyday challenging of the religion/secularism binary. 


\section{References}

Ahmed, Sara. 2017. Living a feminist life. Durham: Duke University Press. Asad, Talal, Judith Butler, Wendy Brown, and Saba Mahmood. 2009. Is critique secular? Blasphemy, injury and free speech. Berkeley: University of California Press.

Bengtsson, Åsa. 2011. Nyktra kvinnor: folkbildare, företagare och politiska aktörer. Vita bandet 1900-1930 [Temperate women: Educators, entrepreneurs and political agents. The White Ribbon 1900-1930]. Dissertation, Lund, Lund University.

Berg, Linda, Mikela Lundahl, and Lena Martinsson. 2016. Sekulariteter: Förstahet genom religion och kön [Secularities: First position through religion and gender]. Kvinder, Køn og Forskning 4: 7-19.

Billig, Michael. 1995. Banal nationalism. London: Sage Publications.

Butler, Judith. 2001. Violence, mourning and politics. Studies in Gender and Sexuality 4 (1): 9-37.

Cadman, Kate, Lorraine Friend, Susanne Gannon, Christine Ingleton, Glenda Koutroulis, Coralie McCormack, Patricia Mitchell, Jenny Onyx, Kerry O’Regan, Sharn Rocco, and Jennie, Small. 2001. Memory-workers doing memory-work on memory-work: Exploring unresolved power. In Memorywork: A critique (Working Paper Series, no. 2001-20), ed. J. Small and J. Onyx, School of Management, University of Technology, Sydney, Australia.

Crawford, June, Susan Kippax, Jenny Onyx, Una Gault, and Pam Benton. 1992. Emotion and gender: Constructing meaning from memory. London: Sage. Davies, Bronwyn, et al. 1997. Ruptures in the skin of silence: A collective biography. Hecate - A Women's Studies Interdisciplinary Journal 23 (1): 62-79.

Eskilsson, Lena. 1991. Drömmen om kamratsambället: Kvinnliga medborgarskolan på Fogelstad 1925-35 [Dream of comradeship: The female civic school at Fogelstad 1925-35/]. Doctorial dissertation, Umeå, Umeå University.

Esseveld, Johanna. 1999. Minnesarbete [memory work]. In Mer än kalla fakta: Kvalitativ forskning i praktiken [more than cold facts: Qualitative research in practice], ed. Katarina Sjöberg. Lund: Studentlitteratur.

Farris, Sara. 2017. In the name of women's rights: The rise of femo-nationalism. Durham/London: Duke University Press.

Fischer, Clara. 2018. Gender and the politics of shame. Special issue. Hypatia 33 (33): 2-10.

Gemzöe, Lena. 2018. Solidarity in head-scarf and pussy bow blouse: Reflections on feminist activism and knowledge production. Social Inclusion 6 (4): 67-81. 
Haug, Frigga. 1987. Female sexualization: A collective work of memory. London: Verso.

- 1992. Beyond female masochism: Memory-work and politics. London: Verso.

Haugen, Hans Morten. 2015. Sweden democrats' appeal to Christianity: Can religious identity politics win general support? Nordic Journal of Religion and Society 28 (1): 77-94.

Hendrix, John Shannon. 2015. Unconscious thought in philosophy and psychoanalysis. Basingstoke: Palgrave Macmillan.

Hirvonen, Vuokko. 2008. Voices from Sápmi: Sámi women's path to authorship. Doctoral thesis, Kautokeino, Norway.

Ideström, Jonas, and Stig Linde. 2019. Welfare state supporter and civil society activist: Church of Sweden in the 'refugee crisis'. Social Inclusion 7 (2): 4-13. Jansson, Maria, Maria Wendt, and Cecilia Åse. 2009. Teaching political science through memory work. Journal of Political Science Education 5 (3): 179-197.

Kaufman, Judith S., Diane Montgomery, Margaret S. Ewing, Adrienne E. Hyle and Patricia A. Self. 1995. Thinking about science through memory work. Paper presented at American Educational Research Association, San Francisco.

Keinänen, Marja-Liisa. 2007. Perspectives on women's everyday religion. Paper at the conference Religion on the borders: New challenges in the academic study of religion. Södertörn University College, Sweden, April 19-22, 2007.

Langdridge, Darren, Meg Barker, Paula Reavey, and Paul Stenner. 2012. Becoming a subject: A memory work study of the experience of romantic jealousy. Forum Qualitative Sozialforschung/Forum: Qualitative Social Research 13 (2): Art. 5.

Longhurst, Robin. 1995. The body and geography. Gender, Place and Culture 2 (1): 97-106.

Mahmood, Saba. 2012. The politics of piety: The Islamic revival and the feminist subject. Princeton: Princeton University Press.

Moraga, Cherrie, and Gloria Anzaldúa. 1983. This bridge called my back: Writings by radical women of color. New York: Kitchen Table, Women of Color Press.

Mulinari, Diana. 2013. Feministiska och postkoloniala reflektioner [Feminist and postcolonial reflections]. In Religionens offentlighet: Om religionens plats $i$ sambället [Public space and religion: On the place of religion in society], ed. Hanna Stenström. Skellefteå: Artos \& Norma Bokförlag.

Nygren, Giritli, Lena Martinsson Katarina, and Diana Mulinari. 2018. Gender equality and beyond: At the cross-roads of neo liberalism, anti-gender movements, 'European values' and normative reiterations in the Nordic model. Social Inclusion 6 (4): 1-6. 
Nyhagen, Line, and Beatrice Halsaa. 2016. Religion, gender and citizenship: Women of faith, gender equality and feminism. Basingstoke: Palgrave Macmillan.

Onyx, Jenny, and Jennie Small. 2001. Memory-work: The method. Qualitative Inquiry 7 (6): 773-785.

Petö, Andrea, and Ann Phoenix. 2019. 'Indelible stains'? Introduction to special issue on gender and memory. European Journal of Women's Studies 26 (3): $237-243$.

Schratz, Michael. 1996. Collaborative, self-critical and reciprocal inquiry through memory work. In New directions in action research, ed. Ortrun Zuber-Skerritt, 66-80. London: Falmer.

Scott, Joan. 1992. Experience. In Feminists theorize the political, ed. Judith Butler and Joan Scott, 22-40. New York: Routledge.

- 2018. Sex and secularism. New Jersey: Princeton University Press.

Sigurdson, Ola. 2009. Det postsekulära tillståndet: Religion, modernitet, politik [The post-secular time: Religion, modernity and politics]. Göteborg: Glänta.

Stephenson, Niamh. 2001. 'Speaking as a woman': Agency in intersubjective communication. Australian Psychologist 36 (1): 19-26.

Thurfell, David. 2019. Det gudlösa folket: de postkristna svenskarna och religionen [The people without God: The post-Christian Swedish people and religion]. Stockholm: Nordstedts.

Tsing, Anna L. 2005. Friction: An ethnography of global connection. Princeton: Princeton University Press.

Willig, Carla. 2001. Introducing qualitative research in psychology: Adventures in theory and method. Buckingham: Open University Press.

Yuval-Davis, Nira. 2011. The politics of belonging: Intersectional contestations. London: Sage.

Linda Berg holds a PhD in Ethnology and is Associate Professor in Gender Studies at Umeå Centre for Gender Studies, Umeå University, Sweden. Berg returns to concepts such as solidarity, subjectivity and place recently through studies of street art and political mobilization. She researches and teaches within the fields of feminism, anti-racism and postcolonial studies.

Anna Johansson is Senior Lecturer at University West (http://www.hv.se/) with a PhD in Sociology (1999) from the University of Gothenburg, Sweden. Her principal areas of research are resistance studies, critical fat studies and gender studies. Among her most recent publications are 'ISIS-chan-the meanings 
of the manga girl in the image warfare against the Islamic State', Critical Studies on Terrorism (2017); Feta män. Maskulinitet, makt och motstånd [Fat men: Masculinity, power and resistance] (2017); 'The Rainbow Flag as Part of the "Apartheid Wall" Assemblage: Materiality, (In)Visibility and Resistance', Journal of Resistance Studies (2019); and Conceptualizing 'everyday resistance': A transdisciplinary approach (2019, with Stellan Vinthagen).

Pia Laskar holds a PhD in the History of Ideas and is Associate Professor in Gender Studies at Stockholm University. Her research interests are intersections between gender, class, and race in the construction of (hetero-)sexual norms and nationhood. Laskar's research and teaching is theoretically rooted in critical gender and sexuality theories and decolonial studies. Her research interests are knowledge production, medical and political history, and, in recent years, also museology and critical heritage studies. Recent publications include the method book Den outställda sexualiteten. Liten praktika för museers förändringsarbete (2019); 'Transnational ways of belonging and queer ways of being. Exploring transnationalism through the trajectories of the rainbow flag' (with Klapeer 2018); 'The displaced Gaze' (2017) and 'The construction of "Swedish" gender through the g-other as a counter-image and threat' (2015).

Lena Martinsson is Professor in Gender Studies at the University of Gothenburg, Sweden. Her main research interests are political subjectivity, social movements and transnationalism in the field of feminist, queer and decolonial studies. Her recent publications include: Challenging the myth of gender equality in Sweden (Martinsson et al. 2016); Dreaming global change, doing local feminisms (Martinsson and Mulinari 2018); Education and political subjectivities in neoliberal times and places: Emergences of norms and possibilities (Reimers and Martinsson 2017).

Diana Mulinari is Professor in Gender Studies at the Department of Gender Studies, Lund University, Sweden. The role of mothers in doing the political was the topic of her PhD in the Department of Sociology at the same university. Questions of colonial legacies, Global North/South relations (with a special focus on Latin America) and racism, and the diversified forms of resistance and organisation to old and new forms of power have stayed with her through all the work she has conducted. Her research has developed in a critical dialogue with feminist and other theoretical and methodological contributions that make a strong case for emancipatory social science. Relevant publications include Dreaming global change, doing local feminisms (Martinsson and Mulinari 2018); 
'A contradiction in terms? Migrant activists in the Swedish Democratic Party', Identities (Mulinari and Neergaard 2018); and 'Exploring femo-nationalism and care-racism in Sweden', Women's Studies International Forum (Sager and Mulinari 2018).

Cathrin Wasshede holds a PhD in Sociology and is Associate Professor at the Department of Sociology and Work Science, the University of Gothenburg. Departing from critical gender studies, queer theory and postcolonial theory, her areas of research mainly concern gender, sexuality, resistance, social movements, children, co-housing and urban sustainability. She has a long and broad experience of teaching within these fields.

Open Access This chapter is licensed under the terms of the Creative Commons Attribution 4.0 International License (http://creativecommons.org/licenses/ by/4.0/), which permits use, sharing, adaptation, distribution and reproduction in any medium or format, as long as you give appropriate credit to the original author(s) and the source, provide a link to the Creative Commons licence and indicate if changes were made.

The images or other third party material in this chapter are included in the chapter's Creative Commons licence, unless indicated otherwise in a credit line to the material. If material is not included in the chapter's Creative Commons licence and your intended use is not permitted by statutory regulation or exceeds the permitted use, you will need to obtain permission directly from the copyright holder.

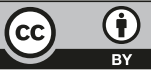

